\title{
Study of size effect using digital image correlation
}

\section{Estudo do efeito de escala utilizando correlação de imagem digital}

A. H. A. SANTOS a ayrtonhugo@yahoo.com.br

R. L. S. PITANGUEIRA a roque@dees.ufmg.br

G. O. RIBEIRO a gabriel@dees.ufmg.br

R. B. CALDAS a caldas@dees.ufmg.br

\begin{abstract}
Size effect is an important issue in concrete structures bearing in mind that it can influence many aspects of analysis such as strength, brittleness and structural ductility, fracture toughness and fracture energy, among others. Further this, ever more new methods are being developed to evaluate displacement fields in structures. In this paper an experimental evaluation of the size effect is performed applying Digital Image Correlation (DIC) technique to measure displacements on the surface of beams. Three point bending tests were performed on three different size concrete beams with a notch at the midspan. The results allow a better understanding of the size effect and demonstrate the efficiency of Digital Image Correlation to obtain measures of displacements.
\end{abstract}

Keywords: size effect, digital image correlation, experimental analysis.

\section{Resumo}

O efeito de escala é uma questão relevante em estruturas de concreto, uma vez que influencia vários aspectos de análise, principalmente aspectos correlacionados com a resistência, fragilidade e ductilidade estrutural, energia e tenacidade à fratura, dentre outros. Além disto, cada vez mais, novas metodologias estão sendo desenvolvidas para avaliar campos de deslocamentos em estruturas. Neste trabalho uma avaliação experimental do efeito de escala é realizada, utilizando como ferramenta de medida a correlação de imagem digital (CID). Vigas de concreto, com três tamanhos distintos e com entalhes no meio do vão, foram ensaiadas por meio do esquema de flexão em três pontos. Os resultados encontrados permitem um melhor entendimento do efeito de escala e demonstram a eficiência da correlação de imagem digital na obtenção de medidas de deslocamentos.

Palavras-chave: efeito de escala, correlação de imagem digital, análise experimental.

Departamento de Engenhenharia de Estruturas, Escola de Engenharia da Universidade Federal de Minas Gerais, , UFMG, Belo Horizonte, MG. 


\section{Introduction}

The size effect is an aspect that should be considered in any physical theory, which is why this subject has been the focus of many engineering problems. This matter is so ancient that it was noted by Leonardo da Vinci in the 1500s, when he performed experimental studies with iron wires of equal diameters and different lengths and observed that tensile strength decreased as the wire length increased.

The study of the size effect was advanced greatly with the creation of fracture mechanics in the work by GRIFFITH [1], where the variation of the elastic energy of solids caused by the presence of faults was investigated, which was linked to the statistical concepts of Mariotte's ideas. This effect is without a doubt, the strongest argument in favor of the use of fracture mechanics to study concrete structures because it influences many aspects of analysis, particularly those correlated to resistance, structural brittleness and ductility, fracture energy, fracture toughness, etc.

Until the early 1980s, there were few studies regarding size effect, which included those performed by KAPLAN [2], KANI [3] and GLUCKLICH [4] in the experimental field and by HILLERBORG et al. [5] in the theoretical field. These studies evidenced a strong dependency between the nature of a concrete fracture and the size effect and indicated the need to relate it to the energy necessary for the propagation of fissures (BAZANT; CEDOLIN [6] and OZBOLT et al. [7])

Currently, the size effect has been analyzed by tests in symmetrical beams subjected to flexural bending at three points, where the span/height ratio is maintained constant and the height is changed according to the specification by RILEM 89-FMT [8]. In these tests, load versus CMOD (crack mouth opening displacement) curves or load versus vertical displacement curves are obtained.

Various techniques can be used to obtain the displacements of such beams, such as digital image correlation (DIC). This tech- nique provides high-resolution measurements of the displacement field on the sample's surface. With DIC, the monitoring points are defined in the area of analysis, and then the relative displacements between these points along the entire field are calculated (NGUYEN et al.[9], RÉTHORÉ et al.[10], ALAM[11]).

In this study, the size effect is evaluated using digital image correlation as a measurement tool. The results allow better observation and understanding of the phenomenon.

\section{Digital image correlation technique}

Digital image correlation (DIC) is an optical method to visualize displacement fields by successive post-processing of captured images at a constant frequency, as explained by SKARŻYŃSKI et al. [12].

This technique uses textural patterns, natural or artificial, as information carriers. Displacement patterns can be obtained by combining the captured image surfaces before and after the deformation or displacement using a function of adequate correlation (SUTTON et al. [13]).

The images are captured by high-precision digital cameras with sensors. The sensors of these cameras are composed of small, photo-sensitive elements, called pixels. When an image is captured, each pixel represents three numbers (color components $\mathrm{Y}$, $\mathrm{Cb}$, and $\mathrm{Cr}$ ) at the proportion of the amount of light reflected by the object being photographed. The $\mathrm{Y}, \mathrm{Cb}$, and $\mathrm{Cr}$ indexes represent luminosity or brightness, blue tonality, and red tonality, respectively. The digital image correlation system should be able to interpret different light intensities and record grayscale patterns for each pixel such that each point is unique.

To use the digital image correlation technique, the system should have at least three functions, as indicated by SKARŻYŃSKI et al. [12], which are (i) image intensity field, (ii) correlation function, and (iii) interpolation function.

Figure 1 - Two successive digital images of an area of interest and respective pixel subsets, which indicates patterns to be observed (SKARŻYŃSKI et al. (12))
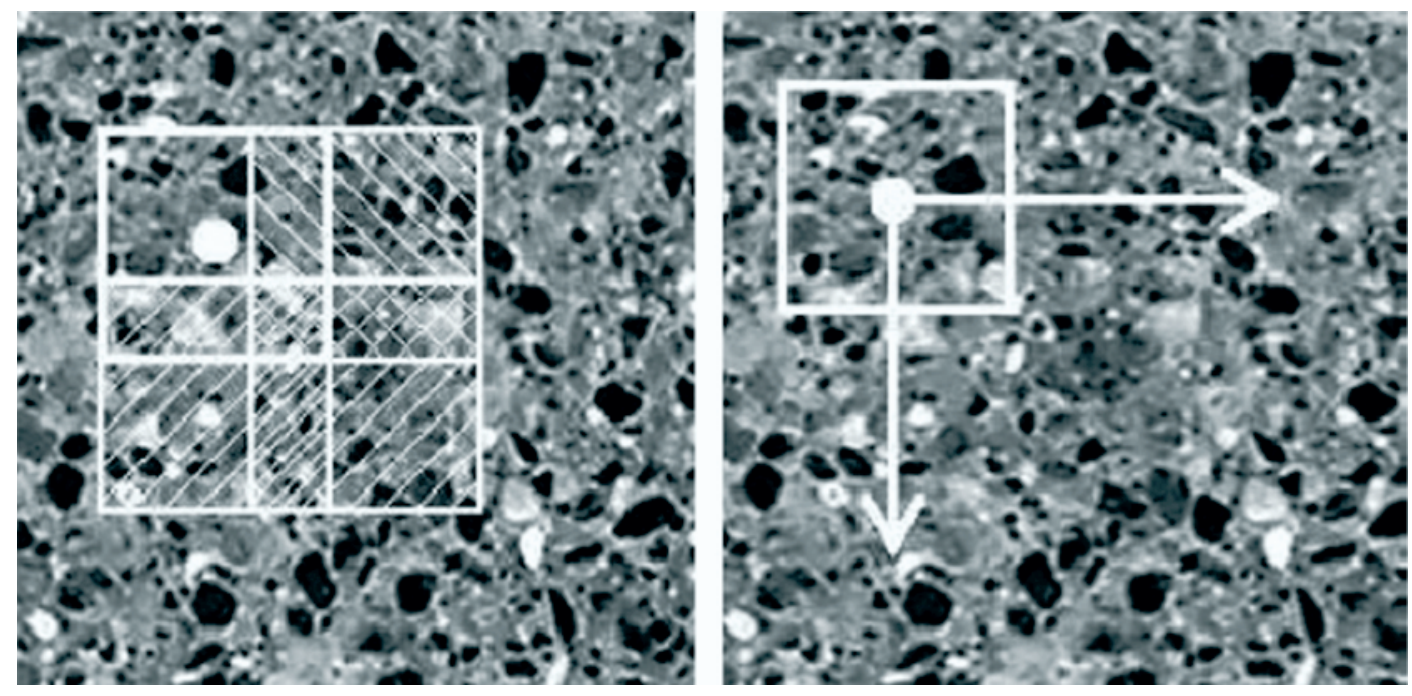


\section{Figure 2 - Digital image capture system (modified) (Pan et al. (14))}

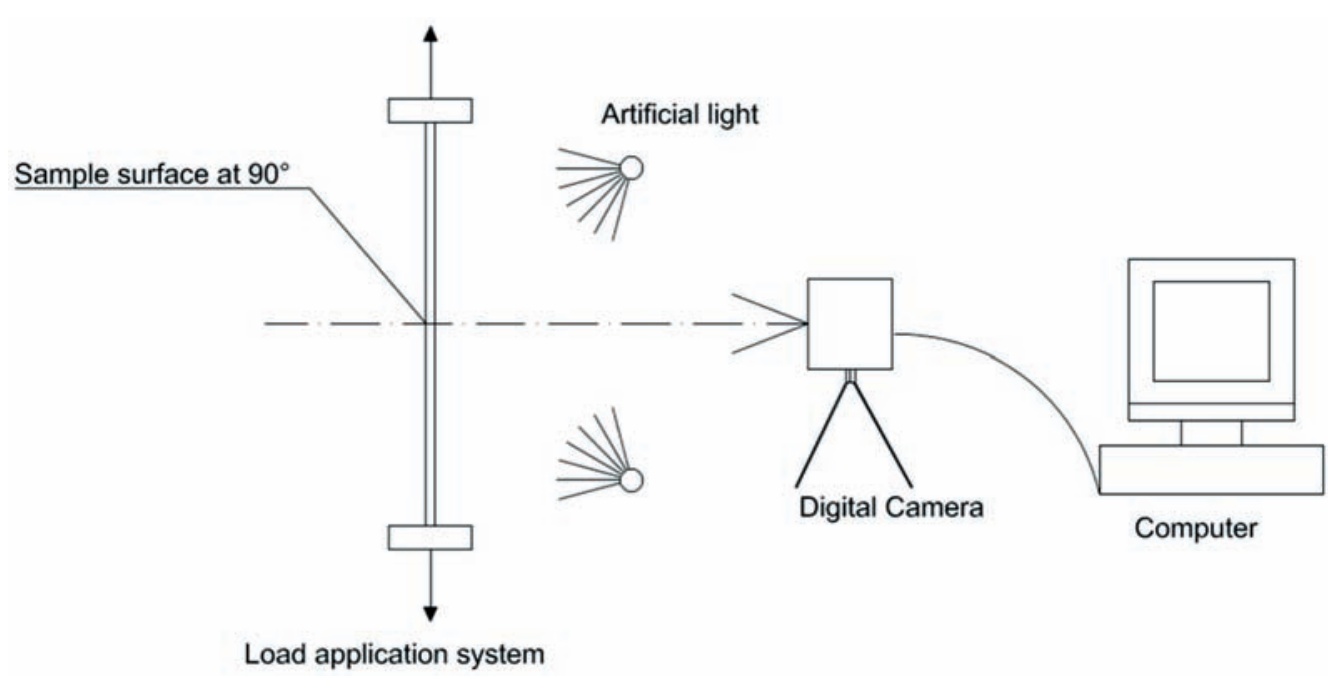

The image intensity field attributes a scalar value to each point of the image plane that represents the light intensity ( $Y$ component) of the corresponding point in the physical space. The image intensity field also indicates the shades of grey that represent the point, which can vary numerically between 0 (black) and 255 (white) for an 8-bit image.

In the digital image, the area of interest should be selected, and small subsets, called patterns, should be chosen. In Figure [1], four patterns are selected in the first image, and the first pattern is observed in the second image. If the displacements of these patterns between two sequential images are too small, their Cartesian positions are considered to have been maintained. The strain pattern is detected by comparing two consecutive images, which are captured by a digital camera that is maintained at a fixed position with its axis oriented perpendicular to the beam's surface plane, as indicated by PAN et al. [14] (Figure [2]).

A local displacement vector is obtained for each pattern (Figure [1]) using a correlation function between two consecutive light intensity distributions ( $Y$ component) in two digital images. The function calculates possible displacements and correlates all grey values from the first image with all of the grey values from the second image. This displacement vector is adjusted using an interpolation function.

In digital cameras, charged coupled devices operate in the $\mathrm{Y}-\mathrm{Cb}$ Cr color space as opposed to the R-G-B color space (R is red, G is green, $B$ is blue). Image storage is preceded by conversion of the

\section{Figure 3 - Diagram of the three-point bending test on a concrete beam}
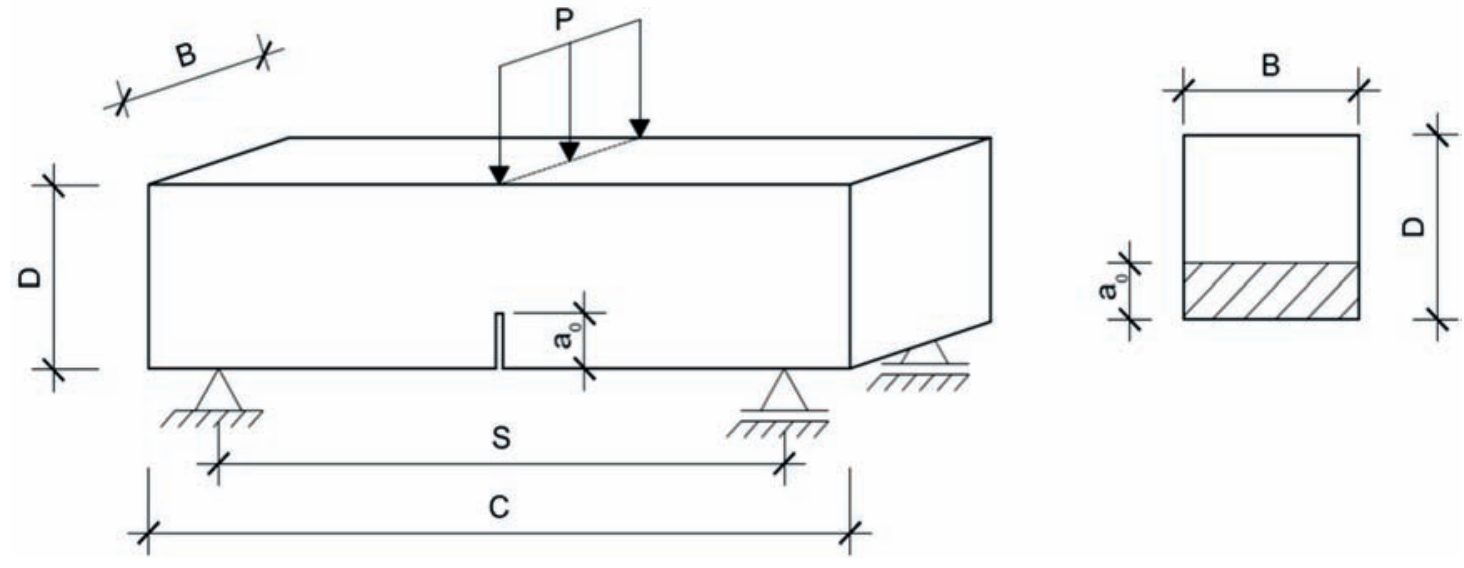


\section{Figure 4 - Grain size curves (a) of aggregated fines (b) of aggregated coarse material}

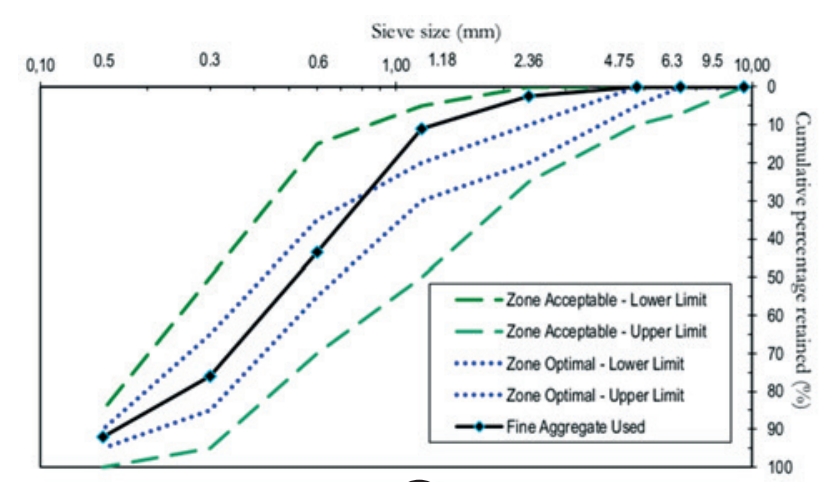

A

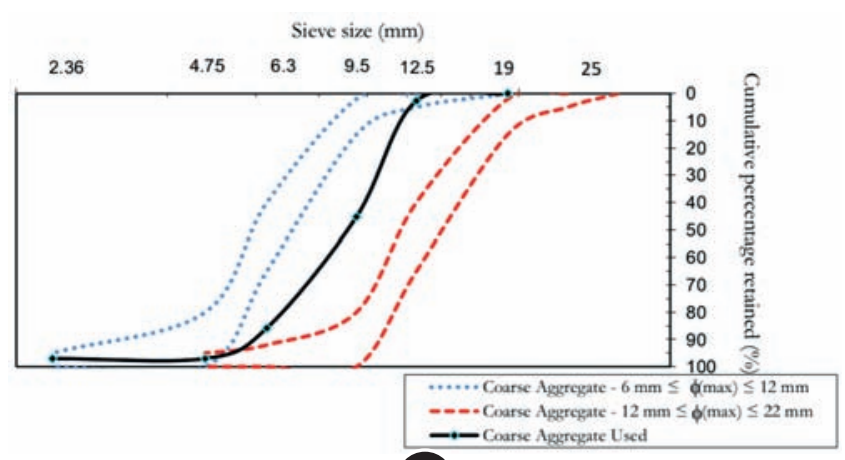

B

R-G-B to the Y-Cb-Cr color space according to Norm ISO/TC42N 4378:1998 [15], as indicated in Equation [1].

$$
\begin{aligned}
& Y=0.2989 R+0.5866 G+0.1145 B \\
& C_{b}=128-0.168736 R-0.331264 G+0.5 B \\
& C_{r}=128+0.5 R-0.418688 G-0.081312 B
\end{aligned}
$$

The precision of the digital image correlation technique is strongly dependent on the size of the pattern selected and on its quality. The pattern spot should contain 4 to 10 pixels on the surface of the specimen, as indicated by SKARŻYŃSKI et al. [12].

\section{Experimental program}

The experimental program consisted of laboratory tests using beams subjected to flexural bending at three points performed in concrete specimens of three different sizes. Table [1] presents the nominal dimensions of the tested beams according to the scheme represented in Figure [3].

The specimens were composed of a rectangular cross-section ( $B$ $x D$ ) with a fixed width of $80 \mathrm{~mm}$ and an effective span (S) equal to four times the section height $D$. The notch at the mid-section of the span $\left(a_{0}\right)$ was maintained at $40 \%$ of the beam height. The notch on the underside of each specimen was wet-cut using a diamond cutting disk with a thickness of approximately $2 \mathrm{~mm}$.

The concrete used was made from a Portland CPII-E32 cement mixture; the fine aggregates had a fineness modulus equal to 2.25 $\mathrm{mm}$, and the coarse aggregates had a maximum diameter of 12.5 $\mathrm{mm}$. Figure [4] presents the grain size curves of the aggregates.

To determine the mechanical parameters of the compressive strength, tensile strength, and static elastic modulus of concrete, an EMIC PC 200 servo-hydraulic machine was used following the recommendations of norms NBR 5739:2007 [16], NBR 8522:2008 [17], and NBR 7222:2011 [18], respectively. The cylindrical specimens measured $10 \mathrm{~cm}$ in diameter and 20 $\mathrm{cm}$ in length. Table [2] presents the values of these mechanical parameters.

To apply the load, a plane frame with an MTS 244.22 actuator with a $100-\mathrm{kN}$ load capacity was used. A $50-\mathrm{kN}$ load cell was coupled to this actuator for compliance of the load-displacement results in the data acquisition system (Figure [5]). The beam displacement control was induced by a vertical displacement " $v$ " imposed on the half span of the beam at a rate of $0.01 \mathrm{~mm} / \mathrm{min}$.

Before the test, the surfaces of the concrete beams were polished and then grid-marked for better monitoring of the standards. The images were captured by a high-resolution USB microscope with a 2.0 megapixel image sensor and video resolution capture of $1280 \times 960$, as presented in Figure [6]. The image capture rate was set at 5 frames per second, which was recorded in an AVI format, and the light was generated by LED lamps from the microscope itself. This equipment along with the digital image process-

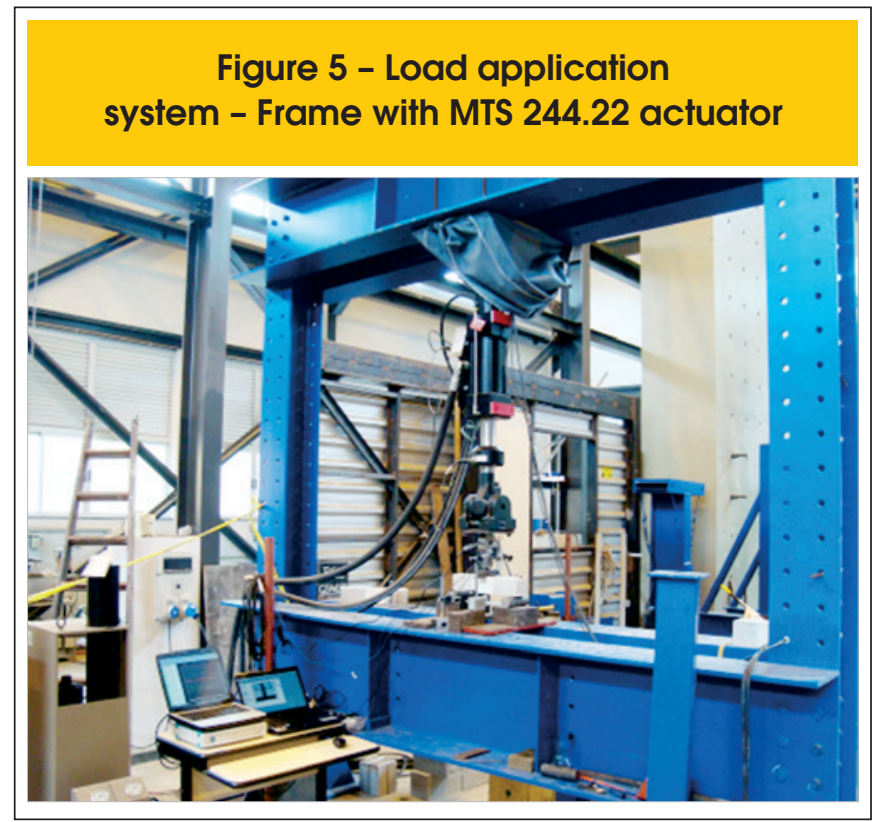




\section{Figure 6 - Concrete beam surface prepared with grid marking and USB Microscope}
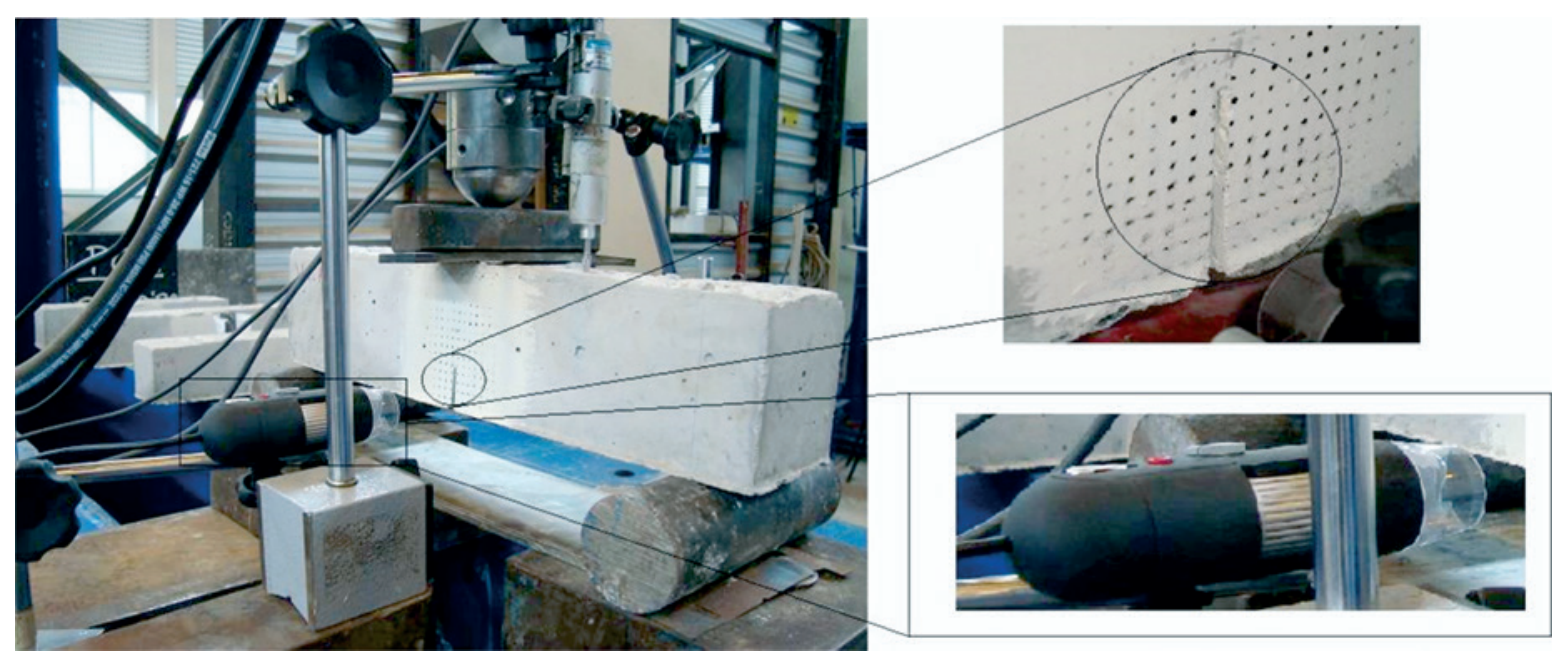

ing software developed in a LabView platform, which was provided by the Graduation Program in Structural Engineering (Programa de Pós-Graduação de Engenharia de Estruturas - PROPEEs) of the Federal University of Minas Gerais (Universidade Federal de Minas Gerais - UFMG), was used to analyze the translation and rotation movements of the monitoring standards; thus, the relative displacements could be determined. The captured images were synchronized with the measurements of the test machine. Next, the results are presented and discussed.

\section{Results and discussion}

For each beam size presented in Table [1], three specimens were tested.

The load versus vertical displacement curves in the mid-span for the three tested sizes are grouped in Figure [7]. The vertical displacement was measured at the underside of the beam. To observe the influence of size on the beams' structural properties, Figure [7] shows the experimental spectra obtained with the corresponding mean curve.

For B2 class beams, during the test performance period, the laboratory went through a layout restructure that required moving the load application system, which created movement in the hoses and a pressure difference in the actuator. Consequently, at the end of the softening of these curves, control was impossible because of the disturbance that occurred in the loading rate due to the pressure relief in the actuator.

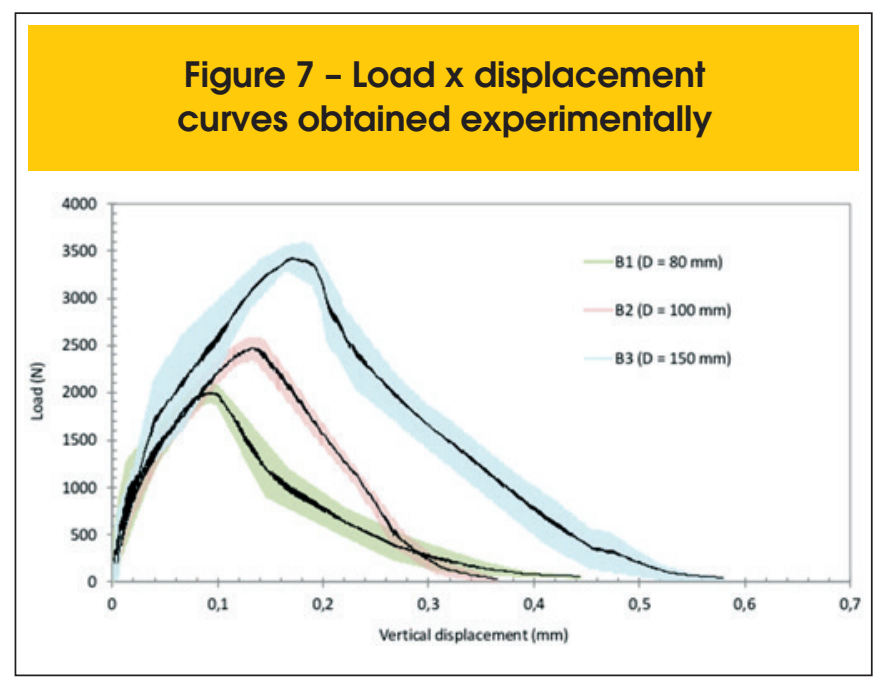

Table 1 - Beam dimensions

\begin{tabular}{|c|c|c|c|c|c|}
\hline Beam & $\begin{array}{l}\text { Total span - C } \\
(\mathrm{mm})\end{array}$ & $\begin{array}{l}\text { Effective span - } S \\
(\mathrm{~mm})\end{array}$ & $\begin{array}{l}\text { Thickness - B } \\
(\mathrm{mm})\end{array}$ & $\begin{array}{l}\text { Height - D } \\
\text { (mm) }\end{array}$ & $\begin{array}{l}\text { Notch }-a_{0} \\
(\mathrm{~mm})\end{array}$ \\
\hline $\mathrm{B} 1$ & 380 & 320 & 80 & 80 & 32 \\
\hline B2 & 450 & 400 & 80 & 100 & 40 \\
\hline B3 & 700 & 600 & 80 & 150 & 60 \\
\hline
\end{tabular}




\begin{tabular}{|cccc|}
\hline \multicolumn{3}{|c|}{ Table 2 } & \multicolumn{3}{|c|}{$\begin{array}{c}\text { Mechanical parameters } \\
\text { of concrete }\end{array}$} \\
\hline Parameter & $\begin{array}{c}\text { Mean } \\
\text { (MPa) }\end{array}$ & $\begin{array}{c}\text { Standard } \\
\text { deviation } \\
\text { (MPa) }\end{array}$ & $\begin{array}{c}\text { Coeff. of } \\
\text { variation } \\
(\%)\end{array}$ \\
\hline $\begin{array}{c}\text { Compressive } \\
\text { strength }\end{array}$ & 35.43 & 3.73 & 10.53 \\
\hline $\begin{array}{c}\text { Elastic } \\
\text { modulus }\end{array}$ & 25982 & 1652 & 6.36 \\
\hline $\begin{array}{c}\text { Tensile } \\
\text { strength }\end{array}$ & 2.93 & 0.31 & 10.50 \\
\hline
\end{tabular}

\begin{tabular}{|c|c|c|c|c|}
\hline \multicolumn{5}{|c|}{$\begin{array}{c}\text { Table } 3 \text { - Fracture energy } G_{F} \text { and brittleness } \\
\text { number }\left(S_{e}\right)\end{array}$} \\
\hline Beam & $\begin{array}{l}\text { Height - D } \\
\text { ( } \mathrm{mm})\end{array}$ & $\begin{array}{c}\text { Area } \\
\text { under } \\
\text { the curve } \\
(\mathrm{N} \times \mathrm{mm})\end{array}$ & $\begin{array}{l}\text { Energy - } G_{F} \\
\quad(N / m)\end{array}$ & $S_{e}$ \\
\hline $\mathrm{B} 1$ & 80 & 302.5 & 78.64 & $3.35 \times 10^{-4}$ \\
\hline B2 & 100 & 425.2 & 88.54 & $3.02 \times 10^{-4}$ \\
\hline B3 & 150 & 840.2 & 116.7 & $2.66 \times 10^{-4}$ \\
\hline
\end{tabular}

\subsection{Size effect on structural ductility}

After calculating the areas under the load-displacement curves presented in Figure [7], the values of the work were obtained, which were equal to $302.5 \mathrm{Nmm}, 425.2 \mathrm{Nmm}$, and 840.2 $\mathrm{Nmm}$ for beam sizes B1, B2, and B3, respectively. Using these values and Equation [2], the respective $G_{F}$ fracture energies were obtained, as presented in Table [3]. An increase in the fracture energy with increases in the specimen size was observed. This fact was also observed by Nallathambi et al. [19] and Karihaloo [20], Gettu et al. [21], and Hillerborg [22] after performing more than 700 three-point flexural tests in beams. The fracture energy values found using DIC varied between 78 and $116 \mathrm{~N} / \mathrm{m}$. These results are extremely similar to those found by Nallathambi et al. [19] and Karihaloo [20], who determined using conventional methods that $G_{F}$ varies between 40 and $130 \mathrm{~N} / \mathrm{m}$ for samples with spans, heights, and notches equivalent to those presented in this study.

The reason why $G_{F}$ varies with specimen size is due to the hypothesis proposed in Equation [2], where all work performed by the external load is completely reversed to the stable propagation of the crack. Figure [8] shows the variation in $G_{F}$ with the height of the specimens (D); this representation is also in accordance with the results presented by Nallathambi et al. [19] and Karihaloo [20].

$$
\text { Energy }=\frac{\text { Area under load }- \text { displacement curve }}{B \cdot\left(D-a_{0}\right)}
$$

Table [3] also presents the brittleness number $\left(S_{e}\right)$ values proposed by Carpinteri [23] and given by Equation [3].

$$
S_{e}=\frac{\mathrm{G}_{\mathrm{F}}}{f_{t} \cdot D}
$$

where $f_{t}$ is the concrete tensile strength, in this case $f_{t}=2.93 \mathrm{MPa}$ according to Table [2].

The present tests indicate that $S_{e}$ is reduced as the beam height increases, which indicates an increase in structural brittleness.

The dimensional analysis used by Carpinteri [23] to define Equation [3] was based on the physical difference of the two intrinsic properties of concrete, i.e., resistance and tenacity. Resistance is defined as the force per unit area or energy per unit volume, whereas tenacity is the energy per unit area. Hence, the energy ratio $\left(S_{e}\right)$ presented includes a dimensional scale of the specimen $(D)$ to generate a dimensionless number. This proposal is based on the fact that what characterizes brittleness or ductility of a structure is not the individual values of $G_{F}$ and $D$ but rather a dimensionless function $\left(S_{e}\right)$. Following this reference, Karihallo [20] concludes that the tendencies in the function of the notch size, height, and free span can all be represented by $S_{e}$ and that as the beam's height increases, $S_{e}$ decreases. This response obtained by conventional methods to obtain the P-Delta curve is in accordance with the results obtained using DIC.

In the study by Karihallo [20], beams with heights varying between 100 and $300 \mathrm{~mm}$ resulted in $S_{e}$ varying between $8.359 \times 10^{-4}$ and $2.09 \times 10^{-4}$. For the present study, beams varying between 80 and

\section{Figure 8 - Variation in fracture energy $\left(G_{F}\right)$ with specimen height (D)}

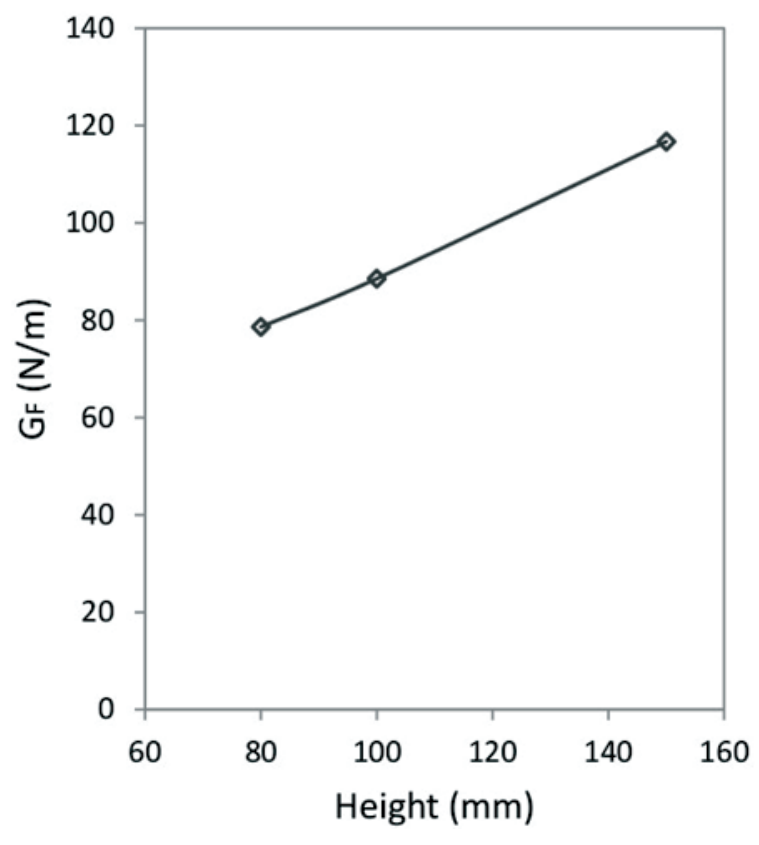


Figure 9 - Dimensionless load versus dimensionless displacement structural response and brittleness number $\left(\mathrm{S}_{\mathrm{e}}\right)$

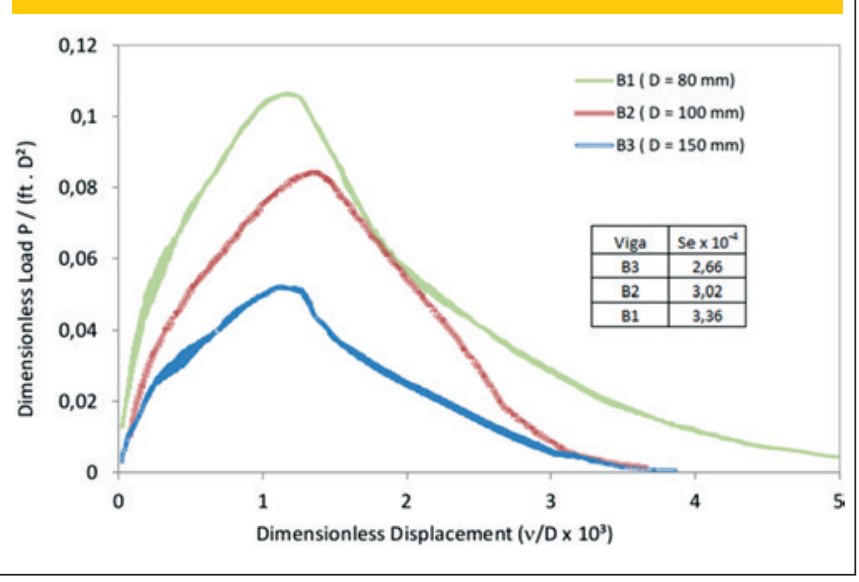

$150 \mathrm{~mm}$ resulted in $S_{e}$ varying between $3.35 \times 10^{-4}$ and $2.66 \times 10^{-4}$. Figure [7] also indicates that the longer the beam, the steeper the slope of the descending section of the trajectory is, which is a direct consequence of the size effect on structural ductility. To improve the visualization of this effect and relate it to the brittleness number $\left(S_{e}\right)$, Figure [9] presents the dimensionless conversion of the curves in Figure [7]. For this purpose, the load values were divided by $\mathrm{ft} D^{2}$, and the displacements were divided by $10^{3} \times D$. The smaller the beam's characteristic dimension, the larger the displacements obtained were, which thus indicates a more ductile behavior.

\subsection{Size effect on nominal strength}

When analyzing the variation in strength according to beam height, the nominal stress $\left(\sigma_{N}\right)$ applied to the beams were determined with the expression defined by PLANAS et al. [24]. (Equation [4]).

$$
\sigma_{N}=\frac{3 \cdot P \cdot S}{2 \cdot B \cdot D^{2}}
$$

where $P$ is the applied load, $S$ is the free span of the beam, $B$ is the section's width, and $D$ is the total height of the entire cross-section outside the notch section.

Figure [10] indicates that the behavior represented by the nominal stress versus vertical displacement curves is different for each beam size. In the pre-peak region, the vertical displacement is greater in beam B3 compared with that of beam B1 regardless of the nominal stress applied. This difference becomes more significant with load increase. This is most likely the result of the absolute length of the notch in B3 beams being larger than that in B1 beams. For the maximum load, a reduction in the nominal stress (nominal resistance) is observed with increases in the specimen size, which thus provides evidence for the size effect. After reaching the maximum load, there is a steep decline in displacement in relation to the nominal stress. This decline is related to the fact that the damage is intensified along the largest part of the beam's section. At the tail of the curve, in the post-critical regimen, the ratio between the vertical displacement and nominal stress begins to exhibit approximately similar behavior for all beams, except for beam B2, which as previously mentioned, exhibited a disturbance in the loading rate.

Figure [11] better demonstrates the size effect, which shows the variation in the vertical displacement and nominal stress in relation to the maximum load for the three beam classes tested.

These data were also analyzed using Bazant's size effect law (BAZANT and PFEIFFER [25], BAZANT and PLANAS [26], RILEM 89-FMT [8]). According to this law, it is possible to characterize what type of fault theory should be applied to a structural project by considering the nominal fault stress $\left(\sigma_{N}\right)$ and the characteristic dimension of the structure $\left(d_{0}\right)$, which will be discussed next. Because of the influence of a relatively large zone of microfissures concentrated at the front of the concrete crack tip (Fracture Process Zone), the beam's strength capacity, as measured by the nominal fault stress, should be studied based on an intermediate
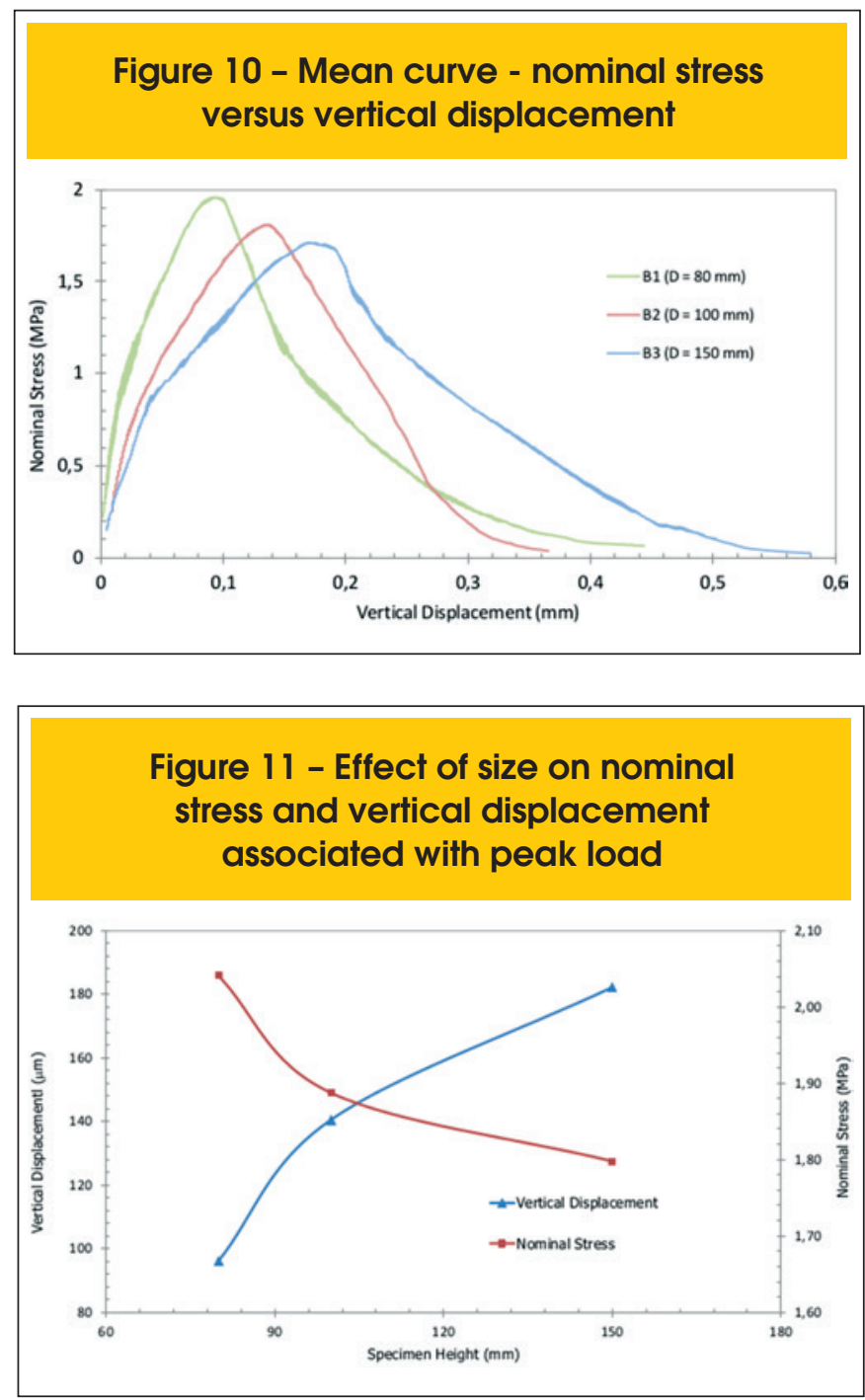


\section{Table 4 - Ultimate tensile strength and fracture parameters}

\begin{tabular}{|ccccc|c|}
\hline & $\begin{array}{c}\sigma \\
(\mathrm{MPa})\end{array}$ & & $\begin{array}{c}\mathrm{d}_{\circ} \\
(\mathrm{mm})\end{array}$ & $\begin{array}{c}\mathbf{B}_{\text {fit }} \\
(\mathrm{MPa})\end{array}$ \\
\hline $\mathbf{B 1}$ & $\mathbf{B 2}$ & $\mathbf{B 3}$ & 161.8 & 0.41 \\
\hline
\end{tabular}

criterion among the classical resistance criteria for concrete structures and linear elastic fracture mechanics (LEFM). Equation [5] expresses the size effect law proposed by Bazant [27], which describes the transition between these theories.

$$
\sigma_{N}=\frac{B f_{t}}{\sqrt{1+\beta}} \quad \text { with } \quad \beta=D / d_{0}
$$

where $f_{t}$ is the material's tensile strength, $d_{0}$ is the material's characteristic size that corresponds to the change of the mechanism between the plasticity phenomenon and the fracture mechanics, $B$ is a parameter of the material, which is a function of the specimen's geometry and of the load applied, and $1 / \beta$ is the structural brittleness number proposed by Bazant [25].

The values of $B f_{t}$ and $d_{0}$ in Equation [5] are obtained by linear regression according to Equation [6] and Equation [7].

$$
Y=A X+C
$$

where

$$
X=D, \quad Y=\left(\frac{1}{\sigma_{N}}\right), \quad B f_{t}=\frac{1}{\sqrt{C}}, \quad d_{0}=\frac{C}{A}
$$

Table [4] presents the fracture parameters determined by the scale effect method and the maximum tensile strengths obtained for beams B1, B2, and B3.

According to the method, $d_{0}$ is the characteristic dimension of the structure located in the point of transition between linear elastic fracture mechanics and the mechanical laws based on strength. In the present analysis, this value is larger than the heights of all specimens used, which thus indicates that a more ductile behavior should be expected for all beams. The brittleness number (Equation [5]) was found to be $0.50,0.62$, and 0.93 for beams B1, B2, and B3, respectively. Therefore, the specimens are at an intermediary stage between plastic behavior $(\beta<<0.1)$ and the transition state $(\beta=1)$. This type of behavior is desirable for concrete so it can be used in civil construction.

The size effect curve proposed by Bazant [26] is presented in Figure [12], where the influence on nominal strength for the three beam classes is observed. The size effect law, i.e., Equation [5],

\section{Figure 12 - Bazant's size effect law}

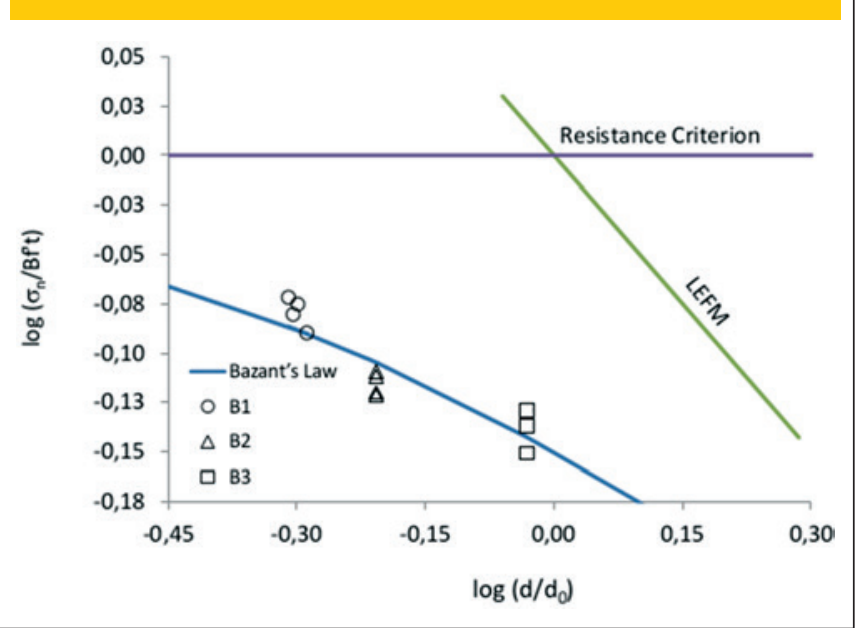

generates a smooth transition between beams B1, B2, and B3, which indicates a good fit of the results obtained.

\section{Conclusion}

In this study, an experimental investigation of the size effect using the digital image correlation technique was performed.

DIC was found to be an effective technique to determine displacement fields on concrete surfaces with the advantage of not requiring physical contact with the specimen's surface.

This technique allowed observing the influence of the size effect on the structural ductility of the beams. According to the calculation of the beams' brittleness number $\left(S_{e}\right)$ via an analysis of the load versus vertical displacement curves, this number indicated an increase in the structural brittleness of the beams as their sizes increased.

Additionally, it was observed that the nominal strength (maximum nominal stress) of the notched concrete beams bent at three points decreases with the increase in the respective characteristic dimension, as has been demonstrated in literature on this subject. Additionally, the experimental results were analyzed based on Bazant's size effect law and were found to completely follow this law.

\section{Bibliographical references}

[1] GRIFFITH, A A., The phenomena of rupture and flow in solids. Philosophical Transactions of the Royal Society of London, v. A 221,1920, p. 163-198.

[2] KAPLAN, F. M., Crack propagation and the fracture of concrete. Journal of the American Concrete Institute, v. 58(11), 1961, p. 591-609.

[3] KANI, G., How safe are our large reinforced concrete beams. ACI Journal. v. 64, 1967, p. 128-141,

[4] GLUCKLICH, J., Fracture of plain concrete. Journal of the Engineering Mechanics Division (ASCE), v. 89, 1963, p. 127-138.

[5] Hillerborg, A., MOdeER, M. e Petersson, P. E. 
Analysis of crack formation and crack growth in concrete by means of fracture mechanics and nite elements. Cement Concrete Research, v. 6, 1976, p. 77̄3-782.

[6] BAZANT, Z. P. e CEDOLIN, L., Stability of Structures: Elastic, Inelastic, Fracture and Damage Theories. Oxford University Press, New York, 1991.

[7] OZBolt, J., Eligehausen, R. e PETRANGELI, M., The size effect in concrete structure. E \& FN Span, 1994, p. 255268.

[8] RILEM 89-FMT, R. D. R. .-F., Size-effect methods for determining fracture energy and process zone size of concrete. Materials and Structure, v. 23,1990, p. 461-465.

[9] NGUYEN, T.L, HALL, S.A, VACHER, P, VIGGIANI, G. Fracture mechanisms in soft rock: identification and quantification of evolving displacement discontinuities by extended digital image correlation. Tectonophysics, v.503, 2011, p.117-128.

[10] RÉTHORÉ, J, TINNES, J.P, ROUX, S, BUFFIĖRE, J.Y, HILD, F. Extended three-dimensional digital image correlation (x3d-dic). Comptes Rendus Mécanique v. 336(8), 2008, p.643-649.

[11] ALAM, S.Y. Experimental study and numerical analysis of crack openings in concrete. PhD thesis, Ecole Centrale de Nantes; 2011.

[12] SKARŻYŃSKI, Ł.; SYROKA, E.; TEJCHMAN, J. Measurements and Calculations of the Width of the Fracture Process Zones on the Surface of Notched Concrete Beams. Strain, v. 47, 2011, p. 319-332.

[13] SUTTON, M. A.; McNEILL, S. R.; HELM, J. D.; CHAO, Y. J. Advances in two-dimensional and three-dimensional computer vision. Top. Appl Phys, v. 77, 2000, p.323-372.

[14] PAN, B., QUIAN, K., XIE, H. e ASUNDI, A., "Two-dimensional digital image correlation for in-plane displacement and strain measurement: a review." Measurement Science and Technology, v. 20, 2009, p. 1-17.

[15] ISO/TC42N 4378, Photography-Electronic Still Picture Imaging-Removable Memory-Part 2: Image Data Format-TIFF/ EP, Nov. 25, 1998.

[16] ASSOCIAÇÃO BRASILEIRA DE NORMAS TÉCNICAS. Concreto - Ensaios de compressão de corpos-de-prova cilíndricos - Métodos de ensaio. NBR 5739, Rio de Janeiro, 2007.

[17] ASSOCIAÇÃO BRASILEIRA DE NORMAS TÉCNICAS. Concreto - Determinação do módulo estático de elasticidade à compressão. NBR 8522, Rio de Janeiro, 2008.

[18] ASSOCIAÇÃO BRASILEIRA DE NORMAS TÉCNICAS. Concreto e argamassa - Determinação da resistência à tração por compressão diametral de corpos-de-prova cilíndricos. NBR 7222, Rio de Janeiro,2011.

[19] KARIHALLO, B. L.; Fracture Mechanics and Structural Concrete. Longman Scientific \& Technical, New York. 1995

[20] NALLATHAMBI, P.; KARIHALLO, B. L. and HEATON, B.S. Effect of specimen and crack size, water/cement ratio and coarse aggregate texture upon fracture toughness of concrete, Mag Concr Res, vol. 36, p.227-236

[21] GETTU, T; BAZANT, Z, P. and KARR, M.E; Fracture properties and brittleness of high strength concrete, $\mathrm{ACl}$ Mater $\mathrm{J}$. vol. 87, p.608-618

[22] HILLERBORG, A. Influence of beam size on concrete frac- ture energy determined according to a draft RILEM recommendation, Report TVBM-3201, Div Bldg Mater Lund Inst Tech, Sweden.

[23] CARPINTERI, A. Notch sensitivity in fracture testing of aggregative materials. Journal Engineering Fracture Mechanical, vol. 16,1982 , p. 467-481

[24] PLANAS, J., GUINEA, G. V. e ELICES, M., Size effect and inverse analysis in concrete fracture. International Journal of Fracture, v. 95, 1999, p. 367-378.

[25] BAZANT, Z. P. e PFEIFFER, P., Determination of fracture energy from size effect and brittleness number. ACI Materials Journal, vol. 84, 1987, p. 463-480.

[26] BAZANT, Z. P. e PLANAS, J. Fracture and Size Effect in Concrete and Other Quasi-Brittle Materials. CRC Press, New York. 1998.

[27] BAZANT, Z. P. Size Effect in blunt fracture: concrete, rock, metal. ASCE Journal Engineering Mechanics, vol. 110, 1984, p. 518-535. 